\title{
Pengaruh Self Efficacy, Skeptisisme Profesional, Independensi, dan Kompleksitas TugasTerhadap Audit Judgment
}

\author{
Gede Teguh Prasetya Muttiwijaya ${ }^{1}$ \\ Dodik Ariyanto ${ }^{2}$ \\ ${ }^{1,2}$ Fakultas Ekonomi dan Bisnis Universitas Udayana (Unud), Bali, Indonesia \\ e-mail:gedeteguhprasetya@gmail.com
}

\begin{abstract}
ABSTRAK
Tujuan penelitian adalah untuk mengetahui pengaruh self efficacy, skeptisisme professional, independensi dan kompleksitas tugas terhadap audit judgment. Penelitian dilakukan di BPK RI Perwakilan Provinsi Bali menggunakan metode non probability sampling dengan Teknik purposive sampling. Jumlah sampel penelitian ini adalah 57 orang auditor di BPK RI provinsi Bali. Berdasarkan hasil penelitiandiketahuiself efficacy, skeptisisme profesional dan independensi berpengaruh positif terhadap audit judgment dan kompleksitas tugas berpengaruh negatif terhadap audit judgment. Implikasi penelitiansecara teoritis dapat berkontribusi dalam pengembangan teori atribusi dan diharapkan dapat bermanfaat bagi semua pihak khususnya BPK RI Perwakilan Provinsi Bali.
\end{abstract}

Kata Kunci: Selfefficacy, skeptisisme profesional, independensi, kompleksitas tugas, audit judgment

\begin{abstract}
The purpose of this study was to determine the effect of self efficacy, professional skepticism, independence and complexity of the task on audit judgment. This research was conducted at the Republic of Indonesia BPK Representative of the Province of Bali using a non probability sampling method with a purposive sampling technique. The total sample of this study was 57 auditors at the BPK RI in Bali province. Based on the results of this study, it is known that self efficacy, professional skepticism and independence have a positive effect on audit judgment and task complexity has a negative effect on audit judgment. The implications of this research can theoretically contribute to the development of attribution theory and are expected to be useful for all parties, especially the Republic of Indonesia BPK Representative of Bali.

Keywords: Self efficacy, professional skepticism, independence, task complexity, audit judgment
\end{abstract}

\section{PENDAHULUAN}

Auditing merupakan proses identifikasi masalah, pengumpulan bukti, serta evaluasi bukti oleh seorang auditor secara objektif dan independen dengan tujuan untuk menilai kebenaran informasi serta memberikan opini atas kewajaran informasi yang tersaji dalam laporan keuangan.Auditing atas laporan keuangan dapat meningkatkan kepercayaan pengguna laporan keuangan atas informasi yang 
tersaji dalam laporan keuangan (Apisti, 2017). Auditor dalam mengevaluasi dan opini audit membutuhkan suatupertimbangan auditatau audit judgment. Hogarth, (1992) mengartikan audit judgment sebagai proses kognitif yang merupakan perilaku pemilihan keputusan. Audit judgment atau pengambilan keputusan audit oleh seorang auditor dibuat berdasarkan pada gagasan, pendapat atau perkiraan mengenai informasi-informasi dari bukti audit yang dipengaruhi oleh faktor teknis dan non teknis sehingga auditor mampu untuk menyatakan kewajaran atas laporan keuangan (Nuarsih dan Mertha, 2017).

Jamilah dkk, (2007) berpendapat,suatu judgment didasarkan pada kejadian-kejadian masa lalu, sekarang, dan yang akan datang. Dalam penetapan opini, audit judgment berperan penting. Audit judgment merupakan suatu pertimbangan pribadi atau cara pandang auditor dalam menanggapi informasi yang mempengaruhi dokumentasi bukti serta pembuatan keputusan pendapat auditor atas laporan keuangan suatu entitas. Audit judgment diperlukan pada saat berhadapan dengan ketidakpastian dan keterbatasan informasi maupun data yang didapat, dimana pemeriksa dituntut untuk bisa membuat asumsi yang bisa digunakan untuk membuat judgment

Judgment juga didefinisikan sebagai proses pembuatan keputusan atau menarik kesimpulan dari antara beberapa kemungkinan solusi alternatif dalam kondisi yang tidak pasti dan berisiko(Heyraniet all,2016).Judgment dalam audit digunakan untuk menentukan risiko audit, penentuan jumlah bukti dan pemilihan bukti. Cara pandang pemeriksa dalam menanggapi informasi berhubungan dengan tanggung jawab dan risiko audit yang akan dihadapi oleh auditor 
sehubungan dengan judgment yang dibuatnya. Kualitas dari audit judgment ini yang akan menunjukkan seberapa baik kinerja seorang auditor dalam melakukan tugasnya (Nadhiroh, 2010). Kemampuan auditor untuk memformulasikan judgment ini dengan tepat sangat penting, karena mereka dapat dimintai pertanggungjawaban hukum jika laporan keuangan yang diaudit terbukti secara material keliru(Joyce dan Biddle, 2017).Faktor-faktor yang mempengaruhi auditor dalam membuat audit judgmentantara lain adalah self efficacy, skeptisisme professional, independensi dan kompleksitas tugas.

Self efficacy merupakan kepercayaan diri auditor bahwa dirinya mampu menyelesaikan tugas-tugas yang diberikan dengan baik, kepercayaan akan diri sendiri dan self control yang baik akan melahirkan audit judgment yang baik (Mullis and Hatfield, 2018). Independensi adalah suatu sikap dan tindakan dalam melaksanakan Pemeriksaan untuk tidak memihak kepada siapapun dan tidak dipengaruhi oleh siapapun. Pemeriksa harus objektif dan bebas dari benturan kepentingan (conflict of interest) dalam melaksanakan tanggung jawab profesionalnya. Skeptisisme professional adalah sikap yang selalu mempertanyakan kebenaran dan validitas bukti bukti yang telah dikumpulkan. Kompleksitas tugas juga merupakan salah satu faktor yang berpengaruh terhadap dalam mengambil suatu judgment. Banyaknya jumlah informasi yang harus diproses dan tahapan pekerjaan yang harus dilakukan untuk menyelesaikan sebuah pekerjaan mengindikasikan auditor dalam posisi tingkat kompleksitas tugas. Faktor-faktor diatas akan mempengaruhi kualitas dari audit judgment yang dibuat oleh auditor, semakin baik kualitas audit judgment yang dibuat maka hasil 
Gede Teguh Prasetya Muttiwijaya dan Dodik Ariyanto. Pengaruh ...

audit akan semakin baik sehingga dapat menjami informasi yang terdapat dalam laporang keuangan.

Dalam sektor pemerintahan perlu dilakukan audit untuk menjamin pengelolaan keuangan negara dilakukan dengan baik, transaparan, akuntabel sesuai dengan peraturan perundang-undangan yang berlaku serta untuk menghindari praktik-praktik korupsi atas kekayaan negara oleh karena itu harus dilakukan pemeriksaan keuangan yang didasarkan atas audit judgment yang baik. Pemeriksaan keuangan negara adalah proses identifikasi masalah, analisis dan evaluasi yang dilakukan secara independent, objektif, dan profesional berdasarkan standar pemeriksaan, untuk menilai kebenaran, kecermatan, kredibilitas, dan keandalan informasi mengenai pengelolaan dan tanggung jawab keuangan negara.

Pemeriksaan keuangan negara memberikan keyakinan yang memadai atas laporan keuangan negara. Pemeriksaan dilakukan dalam rangka untuk mendorong tata kelola keuangan negara yang baik melalui perolehan keyakinan bahwa pengelolaan dan tanggung jawab keuangan negara telah sesuai dengan ketentuan peraturan perundang-undangan dan/atau prinsip-prinsip tata kelola yang baik (BPK RI, 2017). Pemeriksaan pengelolaan dan tanggung jawab keuangan negara merupakan salah satu unsur penting dalam terciptanya akuntabilitas publik.

Undang-undang Nomor 15 Tahun 2006 pasal 6 ayat (1) tentang Badan Pemeriksa Keuangan menyebutkan bahwa Badan Pemeriksa Keuangan Republik Indonesia (BPK RI) bertugas untuk memeriksa pengelolaan dan tanggung jawab keuangan negara yang dilakukan oleh Pemerintah Pusat, Pemerintah Daerah, Lembaga Negara lainnya, Bank Indonesia, Badan Usaha Milik Negara, Badan 
Layanan Umum, Badan Usaha Milik Daerah, dan lembaga atau badan lain yang mengelola keuangan negara. BPK RI sebagai auditor pemerintah yang independen, harus mampu menjadi auditor profesional yang menyediakan jasanya kepada masyarakat umum terutama dalam bidang audit atas laporan keuangan yang dibuat oleh entitas yang diperiksanya.

Standar Akuntansi Pemerintahan berbasis akrual (accrual basis) mewajibkan entitas pelaporan menghasilkan tujuh laporan keuangan dalam pertanggungjawaban kepala daerah kepada masyarakat (public accountability). Pemeriksa dalam melaksanakan pemeriksaan laporan keuangan berpedoman pada Standar Pemeriksaan Keuangan Negara (SPKN) dan Panduan Manajemen Pemeriksaan (PMP). Pelaksanaan audit terhadap laporan keuangan pemerintah dan pemberian opini atas kewajarannya membutuhkan suatu judgment dalam suatu proses audit.

Masyarakat sekarang mulai mempertanyakan eksistensi auditor BPK sebagai pihak yang independen. Hal ini disebabkan karena terjadinya tindakantindakan kecurangan dan penyelewengan yang mungkin ataupun telah dilakukan oleh auditor BPK. Adapun beberapa kasus yang terkait dengan kecurangan yang dilakukan oleh para auditorBPK yaitu kasus yang melibatkan dua orang pegawai BPK Sulawesi Utara yaitu Bahar dan Munzir. Majelis Hakim Pengadilan Tipikor Manado menyatakan keduanya bersalah, karena menerima suap Pemkot Tomohon sebesar Rp 1,5 miliar yang diberikan Walikota Tomohon Jefferson Rumajar. Penyerahan suap tersebut terkait dengan tugas terdakwa Bahar dan Munzir sebagai pembuat laporan hasil pemeriksaan (LHP) untuk membuat penilaian 
Gede Teguh Prasetya Muttiwijaya dan Dodik Ariyanto. Pengaruh ...

keuangan Pemkot Tomohon dari Disclaimer menjadi Wajar Dengan Pengecualian (WDP).

Kasus lainya juga terjadi dimana Komisi Pemberantasan Korupsi (KPK) menetapkan empat orang tersangka dalam kasus gratifikasi audit laporan keuangan Kementerian Desa oleh BPK. Suap itu diberikan agar BPK memberikan predikat wajar tanpa pengecualian (WTP) kepada Kemendes Pembangunan Daerah Tertinggal tahun anggaran 2016 dari keempat tersangka yang ditetapkan dalam kasus ini, salah satunya adalah seorang auditor BPK (tempo.com dalam Sari dan Budiartha, 2018). Kasus penyuapan terhadap auditor BPK juga terjadi ditahun 2017 dimana General Manager PT Jasa Marga (Persero) cabang Purbaleunyi, memberikan suap terhadap Auditor Madya pada Sub Auditorat VII B2 Badan Pemeriksa Keuangan (BPK) RI Sigit Yugoharto. Setia diduga menyuap Sigit terkait temuan pemeriksaan dengan tujuan tertentu (PDTT) BPK.

Dari paparan kasus diatas menunjukkan bahwa auditor tersebut tidak mempertahankanindependensinya dan tidak menggunakan kemahiran profesional dengan cermat dan seksama dalam melaksanakan pekerjaan auditor sesuai Standar Pemeriksaan Keuangan NegaraPenelitian mengenai audit judgment telah dilakukan oleh beberapa peneliti, diantaranya: penelitian oleh Penelitian oleh Suwandi (2017) menghasilkan self-efficacy berpengaruh positif terhadap audit judgment, Gasendi dan Herawati (2017) memberikan hasil bahwa self-efficacy memiliki pengaruh yang negatif terhadap audit judgment, penelitian oleh Prastika dan Wirawati (2017)memberikan hasil skeptisisme profesional memperkuat pengaruh pengalaman auditor pada audit judgment. Sementara itu penelitian oleh 
Oktaviana dan Mediatrix (2018) serta Almari dan Nangoi, (2017) memberikan hasil yaitu independensi memiliki pengaruh positif pada audit judgment.Penelitian lain tentang audit judgment dilakukan oleh (Suwandi, 2017), Margaret dan Raharja (2014), Rahmatika, (2017), Sari dan Ruhiyat, (2017)menunjukkan hasil bahwa kompleksitas tugas berpengaruh negatif terhadap audit judgment.

Peneliti memilih lokasi penelitian di kantor BPK RI Perwakilan Provinsi Bali karena BPK RI Perwakilan Provinsi Bali merupakan lembaga independen yang memiliki peran penting dalam mengaudit laporan pengelolalan keuangan negara oleh pemerintah daerah diseluruh kabupaten di provinsi bali dan merujuk pada fenomena-fenomena yang terjadi seperti contoh kasus suap auditor BPK RI yang sudah dipaparkan sebelumnya, menggambarkan bahwa auditor gagal mempertahankan independensinya sehingga menyebabkan turunya kualitas audit judgment dari BPK RI itu sendiri, dalam hal ini peneliti yang bertempat tinggal di Bali sehingga peneliti tertarik untuk melakukan penelitian pada auditor pemerintah di kantor BPK RI Perwakilan RI Provinsi Bali

Ketidakkonsistenan dari hasil penelitian- penelitian sebelumnya tentang topik yang di angkat peneliti juga mendorong peneliti untuk mengkaji lebih lanjut mengenai faktor-faktor yang dapat mempengaruhi audit judgment, khususnya di lingkungan auditor BPKperwakilan provinsi Bali.

Self-efficacy berpengaruh postif terhadap kinerja auditor dalam pembuatan audit judgment, karena ketika seseorang memiliki self-efficacy yang tinggi, maka individu akan mudah menentukan tindakan dan dapat mengatasi hambatan kerja dengan baik, berpikir kreatif serta cenderung untuk berhasil dalam tugasnya 
Gede Teguh Prasetya Muttiwijaya dan Dodik Ariyanto. Pengaruh ...

sehingga meningkatkan kepuasan atas apa yang dikerjakannya (Apsah, 2012). Penelitian oleh penelitian oleh Suwandi(2017)menemukan hasil bahwa, seseorang yang memiliki tingkat self-efficacy yang tinggi akan memberikan hasil yang lebih baik pada audit judgment dibandingkan dengan seseorang yang memiliki tingkat self-efficacy yang rendah.

Hasil penelitian yang dilakukan oleh Nadhiroh, (2010) memperoleh simpulan kompleksitas tugas, orientasi tujuan pembelajaran dan self-efficacy tidak berpengaruh secara signifikan, namun orientasi tujuan penghindaran-kinerja berpengaruh secara negatif dan signifikan dalam pembuatan audit judgment. Hasil penelitian yang dilakukan oleh Apsah, (2012) dan Suwandi, (2017) maka hipotesis yang diajukan adalah:

$\mathrm{H}_{1}$ : Self-efficacy berpengaruh positif pada audit judgment

Seseorang yang memiliki sikap skeptisisme akan bersikap kritis terhadap validitas bukti audit, menggunakan kemahiran profesionalnya dalam melakukan audit judgement, selalu waspada terhadap bukti audit yang bersifat kontradiksi sehingga judgement yang dihasilkanoptimal (Monica, 2018). Penelitian yang dilakukan olehPopova (2013) di USA memberikan hasil bahwa keputusan audit dipengaruhi oleh dua tingkat Skeptisisme (tinggi dan rendah)

Penelitian tersebut didukung oleh penelitianMonica, (2018), Gusti dan Ali (2008) dalam Prihandono (2012) yang memberikan bukti empiris, skeptisisme profesional auditor berpengaruh positif terhadap audit judgment. Skeptisisme profesional auditor dapat dipengaruhi oleh beberapa faktor. Faktorfaktor tersebut antara lain situasi audit yang dihadapi, etika, pengalaman, 
pengetahuan, dan keahlian.Dari hasil penelitian terdahulu diatas maka hipotesis yang diajukan adalah:

$\mathrm{H}_{2}$ : Skeptisisme profesional berpengaruh positif padaaudit judgment.

Independensi adalah "cara pandang yang tidak memihak didalam pengujian audit, hasil evaluasi audit, dan pembuatan laporan keuangan". Independensi juga diatur dalam Standar Pemeriksaan Keuangan Negara BPK RI (2017) berbunyi "Independensi adalah suatu sikap dan tindakan dalam melaksanakan Pemeriksaan untuk tidak memihak kepada siapapun dan tidak dipengaruhi oleh siapapun". Standar ini mengharuskan auditor bersikap independen, artinya tidak mudah dipengaruhi, karena auditor melaksanakan pekerjaannya untuk kepentingan umum.

Penelitian oleh Oktaviana dan Mediatrix (2018) serta Almari dan Nangoi, (2017) memberikan hasil independensi memiliki pengaruh positif pada audit judgment.Justiana (2010) dalam penelitiannya menemukanindependensi berpengaruh positif signifikan terhadap audit judgment. Jadi semakin independen seorang auditor maka akan semakin tepat Audit Judgment yang diberikan.

Seorang auditor yang bersikap independen, maka dapat dihasilkannya audit judgment yang dapat dipercayai oleh banyak pihak dan masyarakat juga dapat bekerja dengan lebih baik. Sebaliknya semakin rendah independensi auditor dapat menghasilkan audit judgment yang rendah. Sikap independensi yang tidak dijaga oleh auditor akan menghasilkan laporan auditan sebagai hasil akhir pekerjaanya tidaksesuai dengan keadaan sesungguhnya.berdasarkan uraian tersebut maka rumusan hipotesis ketiga $(\mathrm{H} 3)$ yaitu: 
$\mathrm{H}_{3}$ : Independensi berpengaruh positif pada audit judgment

Menurut Jamilah dkk, (2007) terdapat dua aspek penyusun dari kompleksitas tugas, yaitu tingkat kesulitan tugas dan stuktur tugas. Tingkat sulitnya tugas selalu dikaitkan dengan banyaknya informasi tentang tugas tersebut, struktur tugas terkait dan kejelasan informasi (information clarity) dari tugas tersebut. Kompleksitas tugas yang tinggi dapat merusak judgment yang dibuat oleh auditor.

Hasil penelitian Rahmatika, (2017) menunjukkan hasilkompleksitas tugas berpengaruh negatif dan signifikan terhadap judgment. Chung dan Monroe, (2001) mengatakan kompleksitas tugas yang tinggi berpengaruh terhadap judgment yang diambil oleh auditor.

Ketika auditor merasa tugas audit yang dihadapinya merupakan tugas kompleks dan ada instruksi tugas yang belum dimengerti, auditor akan mengalami kesulitan dalam membuat judgment profesional. Hal senada juga ditunjukan dalam penelitian Margaret dan Raharja, (2014), Rahmatika, (2017), Sari dan Ruhiyat, (2017) yang menjelaskan bahwa kompleksitas tugas memiliki pengaruhnegatif terhadap audit judgment. Akibatnya judgmentoleh auditor tersebut menjadi tidak sesuai dengan bukti yang diperoleh. Berdasarkan berbagai penjelasan di atas, dapat dirumuskan hipotesis sebagai berikut:

$\mathrm{H}_{4}$ : Kompleksitas tugas berpengaruh negatif pada audit judgment

\section{METODE PENELITIAN}

Penelitian ini dilakukan di kantor BPK RI Perwakilan Provinsi Bali yang berkedudukan di Jalan A. Pangeran Pettarani, Renon Denpasar.Adapun populasi 
dalam penelitian ini yakni seluruh pegawai yang bekerja di kantor Perwakilan BPK RI Provinsi Bali.Metode sampel terdiri dari beberapa anggota yang dipilih dari suatu populasi. Sampel dalam penelitian ini yaitu auditor independen yang bekerja di kantor BPK RI Perwakilan Provinsi Bali, yang memiliki jabatan fungsional dan bersertifikasi diklat auditor ahli BPK. Berdasarkan metode purposive sampling diperoleh sampel berjumlah 57orang yang terdiri dari pemeriksa utama, madya, muda dan pertama seperti pada Tabel 1 berikut ini:

Tabel 1.

Populasi dan Sampel Penelitian

\begin{tabular}{|c|c|c|c|}
\hline No & Jabatan & Populasi & Sampel \\
\hline 1 & Pejabat Struktural & 9 & 0 \\
\hline 2 & Pemeriksa Utama & 1 & 1 \\
\hline 3 & Pemeriksa Madya & 3 & 3 \\
\hline 4 & Pemeriksa Muda & 31 & 31 \\
\hline 5 & Pemeriksa Pertama & 22 & 22 \\
\hline \multirow[t]{2}{*}{6} & Administrasi Umum & 14 & 0 \\
\hline & Jumlah & 80 & 57 \\
\hline
\end{tabular}

Sumber :BPK RI Provinsi Bali, 2018

Pengukuran variabel menggunakan indikator dalam kuesioner yang di adopsi dari penelitian : Chen et all dalam Ummu (2018) untuk variabel self efficacy, Pramudyastuti, (2014) dalam Hartan, (2016) untuk variabel skeptisisme professional,Putra, (2012) untuk variabel independensi, Maengkom, (2016) untuk variabel kompleksitas tugas dan Jamilah dkk, (2007) dalam Prastika dan Wirawati, (2017) untuk variabel audit judgment. 
Tabel 2.

Daftar Variabel, Indikator dan Skala Pengukuran

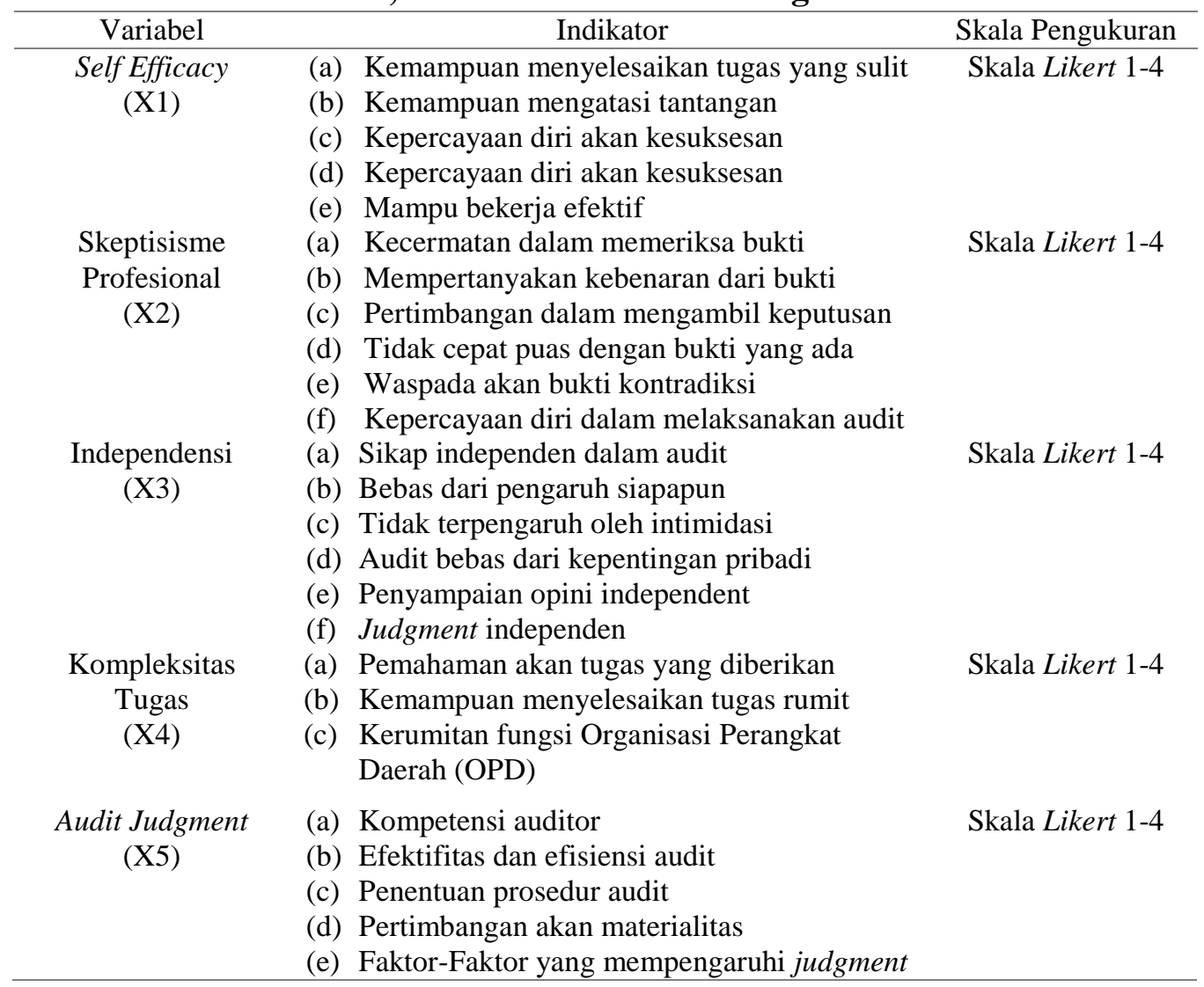

Sumber: Data Diolah,2018

(e) Faktor-Faktor yang mempengaruhi judgment

Teknik analisis data yang digunakan dalam penelitian ini adalah regresi

linear berganda. Analisis regresi linear berganda digunakan untuk mengetahui atau memperoleh gambaran mengenai pengaruh variabel bebas pada variabel terikat. Analisis ini dilakukan dengan menggunakan bantuan program SPSS for windows. Model regresi berganda dalam penelitian ini adalah sebagai berikut:

$\mathrm{Y}=\alpha+\beta_{1} \mathrm{X}_{1}+\beta_{2} \mathrm{X}_{2}+\beta_{3} \mathrm{X}_{3}+\beta_{4} \mathrm{X}_{4}+\varepsilon$

\section{Keterangan:}

$\mathrm{Y}=$ Audit Judgment

$\alpha=$ konstanta

$\beta=$ Koefisien regresi

$\mathrm{X} 1=$ Self Efficacy

$\mathrm{X} 2$ = Skeptisisme Profesional

X3 = Independensi 
$\mathrm{X} 4=$ Kompleksitas Tugas

$\varepsilon=$ Error

Sebelum dilakukan pengujian hipotesis data terlebih dahulu harus lolos uji : validitas, reliabilitas dan uji asumsi klasik. Pengujian hipotesis menggunakan uji statisitik dan uji Koefisien Determinasi (Adjusted $R^{2}$ ). Untuk menguji hipotesis dengan uji statistik mengenai pengaruh Self Efficacy, Skeptisisme Profesional, Independensi, Kompleksitas Tugas terhadap Audit Judgment auditor BPK RI Perwakilan Bali digunakan dua bentuk pengujian hipotesis yakni secara simultan dengan uji $F$ (pengaruh Self Efficacy, Skeptisisme Profesional, Independensi, Kompleksitas Tugas terhadap Audit Judgment Auditor BPK RI Perwakilan Provinsi Bali) dan secara parsial dengan uji $t$ (untuk melihat pengaruh masing masing variabel terhadap judgment Auditor BPK RI Perwakilan Provinsi Bali).

\section{HASIL DAN PEMBAHASAN}

Kuesioner dibagikan kepada 57 Auditor di BPK RI Perwakilan Provinsi Bali yang terlibat dalam proses pemeriksaan terhadap Laporan Keuangan Pemerintah Daerah (LKPD) karakteristik responden dalam penelitian ini ditinjau berdasarkan jenis kelamin, pengalaman bekerja, serta pendidikan terakhir 
Tabel 3.

Karakteristik Responden

\begin{tabular}{ccccc}
\hline No & Kriteria & Klasifikasi & $\begin{array}{c}\text { Jumlah } \\
(\text { Orang })\end{array}$ & $\begin{array}{c}\text { Presentase } \\
(\%)\end{array}$ \\
\hline 1 & Jenis Kelamin & Laki-Laki & 32 & 61,54 \\
& & Perempuan & 20 & 38,46 \\
2 & Jumlah & & 52 & 100 \\
& Pengalaman & $0-5$ & 41 & 78,84 \\
& Bekerja & $5-10$ & 8 & 15,38 \\
& & $>10$ & 3 & 5,77 \\
3 & Jumlah & & 52 & 100 \\
& Pendidikan & S1 & 43 & 82,69 \\
& & $\mathrm{~S} 2$ & 9 & 17,31 \\
& Jumlah & & 0 & - \\
& & & 52 & 100 \\
\hline
\end{tabular}

Karakteristik responden berdasarkan jenis kelamin menjelaskan mengenai proporsi auditor laki - laki dan perempuan. Tabel 3 menunjukan bahwa mayoritas responden adalah laki-laki sebanyak 32 orang $(61,54 \%)$ dan jumlah responden perempuan sebanyak 20 orang $(38,46 \%)$

Karakteristik responden berdasarkan pengalaman bekerja untuk mengetahui lamanya auditor tersebut bekerja di BPK. Tabel 3 menunjukan bahwa diantaranya terdapat auditor yang bekerja selama 0-5 tahun sebanyak 41 orang $(78,84 \%)$, selama $5-10$ tahun sebanyak 8 orang $(15,38 \%)$ dan diatas 10 tahun sebanyak 3 orang atau $5,77 \%$

Karakteristik responden berdasarkan pendidikan terakhir untuk mengetahui tingkat pemahaman intelektual responden. Tabel 3 menunjukan bahwa mayoritas responden berpendidikan terakhir S1 sebanyak 43 orang $(82,69 \%)$, responden yang berpendidikan S2 sebanyak 9 orang $(17,31 \%)$ dan tidak ada responden yang berpendidikan terakhir S3. 
Analisis statistik deskriptif dipergunakan untuk menggambarkan atau menjelaskan suatu data pada variabel penelitian berdasarkan jumlah sampel, nilai rata - rata (mean), standar deviasi, nilai maksimum, dan nilai minimum

Tabel 4.

Hasil Statistik Deskriptif

\begin{tabular}{lccccc}
\hline \multicolumn{1}{c}{ Variabel } & $\mathrm{N}$ & Min. & Max. & Mean & Std. Deviasi \\
\hline Self Efficacy & 52 & 16.00 & 32.00 & 25.980 & 4.203 \\
Skeptisme Profesional & 52 & 15.00 & 28.00 & 23.365 & 3.520 \\
Independensi & 52 & 16.00 & 24.00 & 21.096 & 2.545 \\
Kompleksitas Tugas & 52 & 13.00 & 24.00 & 19.942 & 3.114 \\
Audit Judgment & 52 & 22.00 & 32.00 & 27.307 & 3.177 \\
\hline
\end{tabular}

Sumber: Data diolah, 2018

Self Efficacy (X1) memiliki nilai terendah 6,00, nilai tertinggi sebesar 32.00, nilai rata-rata 25,980 dan standar deviasinya 4,203. Hal ini menunjukan standar penyimpangan data terhadap nilai rata-ratanya adalah 4,203Nilai rata-rata 25,980menunjukkan secara rata-rata jawaban responden cenderung mengarah ke nilai maksimal, yang artinya sebagian besar responden cenderung mengarah ke nilai tertinggi yang artinya persepsi responden mengenaiself efficacy dalam pembuatanaudit judgmentcenderung tinggi

Skeptisisme profesional memiliki nilai terendah 15,00 , nilai tertinggi 28,00, nilai rata-rata 23,365 dan standar deviasinya 3,520. Hal ini menunjukan standar penyimpangan data terhadap nilai rata-ratanya adalah 3,520. Nilai ratarata 23,365 menunjukkan secara rata-rata jawaban responden cenderung mengarah ke nilai maksimal, yang artinya sebagian besar responden cenderung mengarah ke nilai tertinggi yang artinya persepsi responden mengenaiskeptisisme profesionaldalam pembuatanaudit judgmentcenderung tinggi.

Independensi memiliki nilai terendah 16,00 , nilai tertinggi 24,00 , nilai rata-rata 21,096 dan standar deviasinya 2,545. Hal ini menunjukan standar 
Gede Teguh Prasetya Muttiwijaya dan Dodik Ariyanto. Pengaruh ...

penyimpangan data terhadap nilai rata-ratanya adalah 2,545. Nilai rata-rata 23,365 menunjukkan secara rata-rata jawaban responden cenderung mengarah ke nilai maksimal, yang artinya sebagian besar responden cenderung mengarah ke nilai tertinggi yang artinya persepsi responden mengenaiindependensi dalam pembuatan audit judgment cenderung tinggi.

Kompleksitas tugas memiliki nilai terendah 13.00, nilai tertinggi 24,00, nilai rata-rata 19,942 dan standar deviasinya 3,114. Hal ini menunjukan standar penyimpangan data terhadap nilai rata-ratanya adalah 3,114. Nilai rata-rata 19,942 menunjukkan secara rata-rata jawaban responden cenderung mengarah ke nilai minimal, yang artinya sebagian besar responden cenderung mengarah ke nilai terendah yang artinya persepsi responden mengenaikompleksitas tugasdalam pembuatanaudit judgmentcenderung rendah.

Audit Judgment memiliki nilai terendah 22,00, nilai tertinggi 32,00, nilai rata-rata 27,307 dan standar deviasinya 3,177. Hal ini menunjukan standar penyimpangan data terhadap nilai rata-ratanya adalah 3,177. Nilai rata-rata 27,307 menunjukkan secara rata-rata jawaban responden cenderung mengarah ke nilai maksimal, yang artinya sebagian besar responden cenderung mengarah ke nilai tertinggi yang artinya persepsi responden pembuatanaudit judgmentcenderung tinggi.

Analisis regresi linier berganda ini digunakan untuk menganalisis pengaruh self efficacy $\left(\mathrm{X}_{1}\right)$, skeptisme profesional $\left(\mathrm{X}_{2}\right)$, independensi $\left(\mathrm{X}_{3}\right)$ dan kompleksitas tugas $\left(\mathrm{X}_{4}\right)$ terhadap audit judgment $(\mathrm{Y})$. Tabel 5 menunjukkan hasil analisis regresi linier berganda sebagai berikut: 
Tabel 5.

Hasil Uji Regresi Linear Berganda

\begin{tabular}{|c|c|c|c|c|c|c|}
\hline \multirow{2}{*}{\multicolumn{2}{|c|}{ Model }} & \multicolumn{2}{|c|}{$\begin{array}{l}\text { Unstandardized } \\
\text { Coefficients }\end{array}$} & \multicolumn{3}{|c|}{$\begin{array}{l}\text { Standardized } \\
\text { Coefficients }\end{array}$} \\
\hline & & B & Std. Error & Beta & $\mathrm{t}$ & Sig. \\
\hline \multirow[t]{8}{*}{1} & (Constant) & 16.291 & 3.681 & & 4.426 & .000 \\
\hline & Self Efficacy & .229 & .097 & .303 & 2.354 & .023 \\
\hline & Skeptisme Profesional & .222 & .106 & .246 & 2.097 & .041 \\
\hline & Independensi & .277 & .120 & .222 & 2.296 & .026 \\
\hline & Kompleksitas Tugas & -.299 & .093 & -.293 & -3.197 & .002 \\
\hline & Adjusted R Square & 0,679 & & & & \\
\hline & $\mathrm{F}$ & 27.967 & & & & \\
\hline & Sig. & $.000^{\mathrm{a}}$ & & & & \\
\hline
\end{tabular}

Berdasarkan Tabel 4 dapat disusun persamaan regresi sebagai berikut :

$$
Y=16,291+0,229 X_{1}+0,222 X_{2}+0,277 X_{3}-0,299 X_{4}
$$

Koefisien determinasi (Adjusted $R^{2}$ ) digunakan untuk mengetahui dan mengukur kemampuan model dalam menerangkan variasi variabel independen. Peneliti menggunakan nilai adjusted $R^{2}$ pada saat mengevaluasi yang mana model regresi terbaik, karena tidak seperti $\mathrm{R}^{2}$, nilai adjusted $R^{2}$ dapat naik atau turun apabila satu variabel independen ditambahkan ke dalam model. Hasil uji koefisien determinasi dalam penelitian ini dapat dilihat pada Tabel 5.

Pada Tabel 5. dapat dilihat bahwa hasil analisis pengaruh self efficacyterhadap audit judgment diperoleh nilai signifikansi sebesar 0,023 dengan nilai koefisien beta 0,229 . Nilai signifikansi $0,023<0,05$ mengindikasikan bahwa $\mathrm{H}_{0}$ ditolak dan $\mathrm{H}_{1}$ diterima. Hasil ini mempunyai arti bahwa self efficacyberpengaruh positif dan signifikan terhadap audit judgment, artinya semakin tinggi self efficacy auditor maka auditor tersebut akan mampu untuk menentukan tindakan yang tepat untuk mengatasi hambatan kerja dengan baik, berpikir kreatif dan percaya diri untuk berhasil menyelesaikan tugas-tugas dengan 
kemampuan yang dimilikinya sehinggga akan meningkatkan kualitas dari audit judgment yang dibuat oleh auditor tersebut.

Berdasarkan hasil statistik deskriptif, pernyataan dengan nilai rata-rata jawaban tertinggi untuk variabel self efficacy adalah pernyataan"Ketika menghadapi tugas yang sulit, saya yakin akan berhasil menyelesaikan tugas tersebut". Hal tersebut menunjukan bahwa ketika menghadapi tugas yang sulit, auditor di BPK RI Perwakilan Provinsi Bali memiliki keyakinan tinggi untuk dapat menyelesaikan tugas-tugas sulit dengan kemampuan yang dimilikinya. Hasil penelitian ini konsisten dengan hasil penelitian Apsah, (2012) dan Suwandi(2017) yang mengatakan bahwa self efficacy berpengaruh positif terhadap audit judgment

Pada Tabel 5. dapat dilihat bahwa hasil analisis pengaruh skeptisme profesional terhadap audit judgment diperoleh nilai Signifikansi sebesar 0,041 dengan nilai koefisien beta 0,222. Nilai Signifikansi $0,041<0,05$ mengindikasikan bahwa $\mathrm{H}_{0}$ ditolak dan $\mathrm{H}_{2}$ diterima. Hasil ini mempunyai arti bahwa skeptisme profesionalberpengaruh positif dan signifikan terhadap audit judgment pada BPK RI Perwakilan Provinsi Bali.Hal ini menunjukan semakin tinggi skeptisisme seorang auditor maka auditor tersebut akan lebih kritis dan jeli dalam melakukan penliaian atas validitas dan reliabilitas bukti-bukti yang sudah dikumpulkan sehingga audit judgmentyang dihasilkan akan optimal.

Hal ini menunjukan dalam melakukan proses pengauditan auditor di BPK RI Provinsi Bali memiliki kepercayaan diri yang tinggi serta menerapkan sikap skeptisisme professional dengan tidak cepat puas terhadap bukti audit yang telah 
dikumpulkan, selalu mempertanyakan reliabilitas serta validitas bukti audit tersebut sehingga memperoleh keyakinan memadai dalam membuat audit judgment. Hasil penelitian ini konsisten dengan hasil penelitianMonica, (2018), Gusti dan Ali, (2008) yang mengatakan bahwa skeptisisme profesional berpengaruh positif terhadap audit judgment

Pada Tabel 5menunjukan hasil analisis pengaruh independensi terhadap audit judgmentmemperoleh nilai Signifikansi sebesar 0,026 dengan nilai koefisien beta 0,277 . Nilai signifikansi $0,026<0,05$ mengindikasikan bahwa $\mathrm{H}_{0}$ ditolak dan $\mathrm{H}_{3}$ diterima. Hasil menunjukan bahwa independensi berpengaruh positif dan signifikan terhadap audit judgment pada BPK RI Perwakilan Provinsi Bali, Semakin tinggi tingkat independensi seorang auditor maka pertimbangan audit yang dibuatnya (audit judgment) akan bebas dari pengaruh siapapun sehingga menghasilkan keputusan yang obyektif sesuai dengan fakta-fakta dan bukti di lapangan.

Berdasarkan hasil statistik deskriptif, pernyataan dengan nilai rata-rata jawaban tertinggi untuk variabel independensi adalah pernyataan "Saya selalu dapat mengetahui dengan jelas bahwa saya harus mengerjakan suatu tugaskhusus" Hal ini menunjukan bahwa penyampaian fakta-fakta dalam laporan hasil pemeriksaan (LHP) auditor di BPK RI Perwakilan Provinsi Bali bebas dari pengaruh siapapun sehingga menghasilkan laporan yang independen dan dapat dipercaya hal ini tentunya juga berpengaruh terhadap pembuatan audit judgment yang lebih baik. Hasil penelitian ini konsisten dengan hasil penelitian Oktaviana 
dan Mediatrix (2018), Almari dan Nangoi, (2017) serta Justiana (2010) yang menyatakan bahwa independensi berpengaruh positif terhadap audit judgment

Pada Tabel 5menunjukan hasil analisis pengaruh kompleksitas tugas terhadap audit judgmentmenunjukan nilai signifikansi sebesar 0,002 dengan nilai koefisien beta $-0,299$. Nilai Signifikansi 0,002 $<0,05$ mengindikasikan bahwa $\mathrm{H}_{0}$ ditolak dan $\mathrm{H}_{4}$ diterima. Hasil ini mempunyai arti bahwa kompleksitas tugas berpengaruh negatif dan signifikan terhadap audit judgment. Semakin kompleks suatu tugas yang diberikan maka kemampuan auditor dalam membuat suatu keputusan akan mengalami penurunan. Ketika auditor merasa bahwa tugas audit yang dihadapinya merupakan tugas yang kompleks dan ada instruksi tugas yang belum dimengerti, maka auditor akan mengalami kesulitan dalam membuat judgment professional.

Berdasarkan hasil statistik deskriptif, pernyataan dengan nilai rata-rata jawaban terendah untuk variabel kompleksitas tugas adalah pernyataan "Sejumlah tugas yang berhubungan dengan pembagian fungsi organisasi perangkat daerah (OPD) yang ada, rumit dan membingungkan bagi saya", hal ini menunjukan bahwa tugas- tugas yang berhubungan dengan pembagian fungsi perangkat daerah (OPD) yang ada dirasa rumit dan membingungkan bagi auditor sehingga hal ini berdampak terhadap sulitnya penentuan audit judgment yang tepat. Hasil penelitian ini konsisten dengan hasil penelitian Rahmatika, (2017), Chung dan Monroe, (2001),Margaret dan Raharja, (2014) yang menyatakan bahwa kompleksitas tugas berpengaruh negatif terhadap audit judgment. 
Penelitian ini dapat mendukung teori atribusi oleh Heider, (1958)yang menyatakan bahwa perilaku seseorang ditentukan oleh kombinasi antara kekuatan internal (internal forces), yaitu faktor-faktor yang berasal dari dalam diri seseorang, seperti kemampuan atau usaha, dan kekuatan eksternal (eksternal forces), yaitu faktor-faktor yang berasal dari luar seperti kesulitan dalam pekerjaan atau keberuntungan. Dalam hal ini pembuatan audit judgment yang dilakukan oleh auditor dipengaruhi oleh faktor - faktor dari dalam diri auditor yaitu self efficacy, independensi dan skeptisisme professional auditor yang berpengaruh positif terhadap audit judgment dan faktor eksternal yang mempengaruhi adalah kompleksitas tugas yang berpengaruh negatif terhadap pembuatan audit judgment

Bagi peneliti, penelitian ini dapat menambah wawasan mengenai faktor faktor yang mempengaruhi pembuatan audit judgment pada BPK RI Perwakilan Provinsi Bali, bagi pihak-pihak yang berkepentingan serta dapat dijadikan acuan untukpenelitian-penelitian selanjutnya. Bagi profesi auditor pemerintah, penelitian ini mampu memberikan informasi kepada auditor BPK RI Perwakilan Provinsi Bali untuk pertimbangan dalam pembuatan judgment yang tepat sehingga dapat memberikan kontribusi terhadap ketepatan opini akhir mengenai kewajaran laporan keuangan pemerintah daerah.

\section{SIMPULAN}

Self efficacy berpengaruh positif dan signifikan terhadap audit judgment yang dibuat oleh auditor pada BPK RI Perwakilan Provinsi Bali, hal ini berarti semakin 
tinggi self efficacy yang dimiliki oleh auditor maka auditor akan bersikap optimis terhadap kemampuannya dalam menyelesaikan masalah serta dapat berpikir kreatif ketika melaksanakan tugas-tugasnya sehingga hasil dari audit judgment semakin baik.

Skeptisisme professional berpengaruh positif dan signifikan terhadap audit judgment , hal ini berarti bahwa semakin tinggi skeptisisme professional auditor maka auditor akan lebih teliti dan kriktis dalam memeriksa validitas dan reliabilitas bukti - bukti audit sehingga audit judgment yang dibuat akan lebih optimal

Independensi berpengaruh positif signifikan terhadap audit judgment ini berarti semakin tinggi sikap independensi yang dimiliki oleh seorang auditor makadalam membuat suatu pertimbangan maupun keputusan audit (audit judgment) akan bebas dari pengaruh siapapun sehingga penilaian auditor akan bersifat obyektif, hal ini akan meningkatkan kualitas dari audit judgment

Kompleksitas tugas berpengaruh negatif signifikan terhadap audit judgment, hal ini berarti ketika auditor merasa bahwa tugas audit yang dihadapinya merupakan tugas yang kompleks dan ada instruksi tugas yang belum dimengerti, maka auditor akan mengalami kesulitan melaksanakan audit dan melakukan penilaian atas bukti-bukti audit sehingga akan berpengaruh buruk dalam pembuatan audit judgment.

Berdasarkan statistik deskriptif menunjukan bahwa pernyataan dengan nilai rata-rata jawaban terendah untuk variabel self efficacy adalah pernyataan "Bahkan ketika hal-hal yang sulit, saya bisa tampil cukup baik.", hal ini 
menunjukan ketika berhadapan dengan tugas sulit, auditor BPK RI Perwakilan Provinsi Bali mengalami kesulitan mencapai hasil yang baik untuk tugas tersebut. Jadi saran dari peneliti adalah auditor dapat meningkatkan pengalaman serta wawasan yang dimiliki mengenai audit pemerintahan, mengingat data responden menunjukan bahwa mayoritas auditor di BPK RI Perwakilan Provinsi Bali baru memiliki pengalaman 0-5 tahun sehingga ketika auditor memiliki pengalaman dan wawasan yang luas terhadap audit pemerintahan maka diharapkan dalam penyelesaian tugas akan memberikan hasil yang lebih optimal

Berdasarkan hasil statistik deskriptif, pernyataan dengan nilai rata-rata jawaban terendah untuk variabel skeptisisme profesional adalah pernyataan "Saya sering menolak informasi tertentu, kecuali menemukan bukti informasi tersebut benar", hal ini menunjukan bahwa auditor masih kesulitan dalam menilai kebenaran suatu informasi sehingga saran dari peneliti adalah auditor diharapkan untuk mempertahankan skeptisisme professional dalam setiap audit serta lebih teliti dalam menganalisis informasi-informasi yang ada.

Berdasarkan hasil statistik deskriptif, pernyataan dengan rata-rata nilai jawaban terendah untuk variabel independensi adalah pernyataan"Dalam menentukan pendapat atas laporan hasil pemeriksaan (LHP), saya bebas dari pengaruh siapapun", hal ini menunjukan bahwa auditor masih terpengaruh faktorfaktor lain dalam menentukan pendapat atas laporan hasil pemeriksaan sehingga akan mempengaruhi kualitas dari laporan hasil pemeriksaan (LHP), saran dari peneliti adalah auditor harus berpedoman terhadap standar pemeriksaan keuangan 
negara (SKPN) dalam menentukan pendapat atas LHP serta tetap menjunjung tinggi independensi agar hasil audit bersifat obyektif.

Berdasarkan hasil statistik deskriptif variabel kompleksitas tugas memiliki skor rata-rata jawaban terendah dibandingkan pernyataan untuk variabel lain sehingga sebaiknya BPK RI Perwakilan Provinsi Bali lebih memperhatikan bagaimana cara mengatasi kompleksitas dari tugas melalui deskripsi jabatan yang jelas, deskripsi jabatan disarankan lebih menunjukan apa yang harus dikerjakan dalam setiap penugasan audit, serta dalam pemberian instruksi tugas dilakukan dengan padat dan jelas sehingga dalam pelaksanaan tugas akan lebih mudah dimengerti yang berdampak pada pembuatan audit judgment lebih baik.

\section{REFERENSI}

Almari, F. and Nangoi, G. B. 2017. Pengaruh Keahlian, Pengalaman, Kompleksitas Tugas dan Independensi terhadap Audit Judgment pada Inspektorat Provinsi Gorontalo. Jurnal EMBA. Universitas Sam Ratulangi, 5, pp. 593-601.

Apisti, O. L. 2017. Pengaruh Tekanan Ketaatan dan Kompleksitas Tugas terhadap Profesional Judgment Auditor. Jurnal Akuntansi. Universitas Negeri Padang, 1, pp. 1188-1197. doi: 10.1111/j.1469-7610.2010.02280.x.

Apsah, S. 2012. Pengaruh Kompleksitas Tugas, Job Stress dan Self Efficacy terhadap Kinerja Auditor dalam Pembuatan Audit Judgment. Jurnal Ekonomi dan Bisnis UIN.

Chung, J. and Monroe, G. 2001. A Research Note on The Effect of Gender and Task Complexity on Audit judgment. Journal of Behavioral Research, 13, pp. 111-125.

Gasendi, E. and Herawati, T. 2017. Pengaruh Kompleksitas Tugas, Orientasi Tujuan, dan Self-Efficacy Terhadap Kinerja Auditor Dalam Pembuatan Audit Judgment. e-Journal S1 Ak Universitas Pendidikan Ganesha, 8.

Heider, F. 1958. The Psychology of Interpersonal Relations, New York: Wiley. 
Heyrani, F., Banimahd, B. and Rahnamayeh, F.2016. Investigation of the Effect of Auditors ' Professionalism Levels on Their Judgment to Resolve the Conflict between Auditor and Management. Procedia Economics and Finance. Elsevier B.V., 36(16), pp. 177-188. doi: 10.1016/S2212567130029-6.

Hogarth, R. 1992. Order Effects in Belief Updating: The Belief-Adjustment Mode. Cognitive Psychology, United States: University of Chicago.

Jamilah, S., Fanani, Z. and Chandrarin, G. 2007. Pengaruh Gender, Tekanan Ketaatan, dan Kompleksitas Tugas terhadap Audit Judgment. Simposium Nasional Akuntansi 10, 2, pp. 1-30.

Joyce, E. J. and Biddle, G. C. 2017. 'Are Auditors' Judgments Sufficiently Regressive?'. Journal of Accounting Research School of Business, University of Chicago, 19, pp. 323-349.

Maengkom, M. C. 2016. Pengaruh Keahlian Audit, Kompleksitas Tugas dan Locus of Control Eksternal Terhadap Audit Judgment. Skripsi Fakultas Ekonomi dan Bisnis Universitas Hasanudidn.

Margaret, A. N. and Raharja, S. 2014. Analisis Faktor - Faktor Yang Mempengaruhi Audit Judgment Pada Auditor BPK RI. Diponegoro Journal of Accounting, 3, pp. 21-33.

Monica, A. N. 2018. Pengaruh Self Efficacy, Locus of Control , Pengalaman Auditor dan Skeptisme Profesional Terhadap Audit Judgment. Jurnal Akuntansi Universitas Muhamadiyah Surakarta, p. 14.

Mullis, C. E. and Hatfield, R. C. 2018. The Effects of Multitasking on Auditors' Judgment Quality. Contemporary Accounting Research, 35, pp. 314-333. doi: 10.1111/1911-3846.12392.

Nadhiroh, S. A. 2010. Pengaruh Kompleksitas Tugas, Orientasi Tujuan dan Self Efficacy terhadap Kinerja Auditor dalam Pembuatan Audit Judgment.Universitas Diponegoro.

Nuarsih, P. and Mertha, M. 2017. Pengaruh Kompleksitas Tugas, Tekanan Ketaatan dan Senioritas Auditor pada Auditor Judgment. E-Jurnal Akuntansi Universitas Udayana, 20.1, pp. 144-172. doi: https://doi.org/10.24843/EJA.2018.v23.i01.p11.

Oktaviana, A. and Mediatrix, M. 2018. Pengaruh Pengalaman Audit , Pengetahuan Mendeteksi Kekeliruan, Independensi Dan Audit Tenure 
Pada Audit Judgment. E-Jurnal Akuntansi Universitas Udayana, 23, pp. 2175-2202. doi: https://doi.org/10.24843/EJA.2018.v23.i03.p21.

Prastika, E. and Wirawati, P. 2017. Skeptisme profesional sebagai variabel pemoderasi pengaruh tekanan ketaatan dan pengalaman auditor pada audit judgment. E-Jurnal Akuntansi Universitas Udayana, 18.3, pp. $1800-1830$.

Putra, N. A. E. 2012. Pengaruh Kompetensi, Tekanan Waktu, Pengalaman Kerja, Etika, dan Independensi Auditor Terhadap Kualitas Audit. Skripsi Fakultas Ekonomi Universitas Negeri Yogyakarta.

Rahmatika, A. 2017. Pengaruh Tekanan Anggaran Waktu, Kompleksitas tugas, Pengetahuan Auditor dan Pengalaman Auditor terhadap Audit Judgment. JOM Fekon, 4.

Sari, D. I. and Ruhiyat, E. 2017. Locus Of Control, Tekanan Ketaatan dan Kompleksitas Tugas Terhadap Audit Judgment. Jurnal ASET (Akuntansi Riset). Universitas Pamulang, 9, pp. 23-34.

Sari, S. and Budiartha. 2018. Self-Efficacy Memoderasi Kompleksitas Tugas, Tekanan Anggaran Waktu, Independensi Terhadap Audit Judgment BPK RI Provinsi Bali Ni. E-Jurnal Akuntansi Universitas Udayana, Vol.23.1., pp. 267-295. doi: https://doi.org/10.24843/EJA.2018.v23.i01.p11.

Suwandi 2017. Pengaruh self efficacy, kecerdasan emosional, tekanan ketaatan dan kompleksitas tugas terhadap audit judgment auditor. E-jurnal Akuntansi Universitas Riau, 2, p. 11. 